\title{
DISCREPANCIES IN ANALYSES OF DEOXYRIBONUCLEIC ACID IN RABBIT SPERMA- TOZOA, INVOLVING FEULGEN STAINING (FEULGEN- DNA) AND ULTRAVIOLET LIGHT ABSORPTION (UV-DNA) MEASUREMENTS
}

\author{
R. BOUTERS, * C. ESNAULT, G. W. SALISBURY \\ AND R. ORTAVANT \\ Animal Physiology Research Center (I.N.R.A.), \\ Jouy-en-Fosas (S. et O.), France, \\ and Department of Dairy Science, University of Illinois, \\ Urbana, U.S.A. \\ (Received 18th Fuly 1966)
}

\begin{abstract}
Summary. The DNA content of individual ejaculated spermatozoa and of spermatozoa recovered from the epididymis and ampulla of fifteen rabbits was measured by means of two microspectrophotometric methods: (i) direct determination of ultra-violet (Uv) light absorbed at $260 \mathrm{~m} \mu$ by unstained spermatozoa, and (ii) determination of visible light absorbed at $560 \mathrm{~m} \mu$ by Feulgen-stained spermatozoa. The DNA determinations in uV light for ejaculated spermatozoa and for those recovered from the male ducts revealed no difference, as contrasted with the results obtained by measuring the Feulgen-stainability. The differences in Feulgen-stainability, i.e. in the quantitative response of spermatozoa to the Feulgen reagent, are attributed to an ageing process in the sperm cells: ampullary spermatozoa yielded significantly lower Feulgen-DNA values than those obtained from the epididymis; ligation of the vas deferens resulted in a decrease of the Feulgen-DNA content of epididymal spermatozoa; the variable Feulgen-DNA content of individual ejaculated spermatozoa is attributed to varying percentages of older sperm cells in the ejaculates.
\end{abstract}

\section{INTRODUCTION}

The published data concerning the DNA content of sperm cells from fertile, subfertile or infertile individuals are contradictory. Using microspectrophotometric methods Weir \& Leuchtenberger (1957), Leuchtenberger (1960) and Welch, Hanly \& Guest (1961) found the DNA values in Feulgen-stained spermatozoa from subfertile men and bulls to be lower and more variable than those from normal individuals. Parez, Petel \& Vendrely (1960) using the same

* Clinic for Obstetrics and Gynaecology, Veterinary School, State University, Ghent, Belgium. 
technique confirmed the greater variability of DNA in sperm cells from infertile bulls but the mean values were higher than in normal animals. On the other hand, when Summerhill \& Olds (1961) calculated the amount of DNA/sperm cell as a mean value based on determinations by extraction of DNA from several million cells, they found no marked correlation between the DNA content of the spermatozoa and their fertilizing capacity, the correlation coefficient being 0.2 .

It was shown by Bouters \& Vandeplassche (1964) that viral testicular degeneration in bulls results in the appearance, in ejaculated semen, together with spermatozoa, of a large amount of chromosomal material desquamated from the germinal epithelium. This phenomenon makes the accuracy of extraction methods for DNA, calculated on a per sperm cell basis, highly questionable in cases of testicular degeneration. However, it does not, of course, explain the contradictory statements in the literature concerning the DNA values determined in single spermatozoa by means of those microspectrophotometer devices which depend on measuring the absorption of light by the Feulgen-DNA complex. Baker \& Salisbury (1963) suggested that the differences between mean areas of dead cells may account for some of the differences in Feulgen-DNA and for the greater variability of DNA content reported in the spermatozoa from infertile as contrasted to those from fertile males. For this reason, it was decided to induce testicular damage in normal rabbits and to measure the content of Feulgen-DNA and UV-DNA of ejaculated spermatozoa and of spermatozoa recovered from different parts of the male ducts both before and after the induction of testicular damage. In the present study Feulgen-DNA is defined as the DNA-value obtained by measuring the absorption of visible light by Feulgen-stained spermatozoa, and UV-DNA is defined as the DNA-value obtained by measuring the absorption of ultra-violet light by unstained spermatozoa. The basis for the Feulgen reaction, as proposed by Feulgen \& Rossenbeck (1924) and as discussed by Walker \& Richards (1959), is that acid hydrolysis breaks the purine-sugar glucoside linkages of the DNA molecule, thus freeing aldehyde groups which react with the Schiff reagent to produce a coloured dye with an absorption maximum at $560 \mathrm{~m} \mu$. The uv-absorption method depends on measuring the absorption of uv-light at $260 \mathrm{~m} \mu$, which is due to unstained and unhydrolysed nucleotides, and must be attributed to purines and pyrimidines (Di Stefano, 1948).

\section{Animals}

\section{MATERIALS AND METHODS}

The experiments were performed on fifteen white sexually mature male rabbits, uniform in age and weight. From two rabbits (Nos. 1 and 2) twenty ejaculates were collected by means of an artificial vagina, and the spermatozoa Feulgen-stained. Three rabbits (Nos. 3, 4 and 5) were slaughtered after one semen collection, and the Feulgen-DNA content of the ejaculated spermatozoa compared with that of spermatozoa recovered from the caput epididymidis, the cauda epididymidis and the ampulla. From eight rabbits (Nos. 6 to 13) three ejaculates were collected before slaughtering; smears were prepared from the caput, the cauda and the ampulla; and both the Feulgen-DNA and UV-DNA measured. Three rabbits (Nos. 3,6 and 10) did not receive any treatment and 
served as controls. To the rabbits Nos. 1, 2, 4, 5, 7, 8, 9, 11, 12 and 13, a hot water spray was applied to the scrotum at $46^{\circ} \mathrm{C}$ for $10 \mathrm{~min}$ (after the collection of one to four ejaculates) in order to provoke testicular damage. In two rabbits (Nos. 14 and 15) a ligature was placed on the left vas deferens caudally from the cauda epididymidis and the animals were killed after 15 days (No. 14) and 30 days (No. 15), respectively.

Smears for Feulgen staining

Smears were prepared in duplicate on glass slides, fixed above $40 \%$ formaldehyde at room temperature for $15 \mathrm{~min}$ and stained on the same day. The main steps in the standard procedure were: treatment with tap-water, $15 \mathrm{~min}$; distilled water, $5 \mathrm{~min}$; $\mathrm{N}-\mathrm{HCl}$ at $60^{\circ} \mathrm{C}, 11 \mathrm{~min}$; distilled water, $5 \mathrm{~min}$; Schiff reagent, $\mathrm{I} \mathrm{hr} ; 10 \% \mathrm{Na}_{2} \mathrm{~S}_{2} \mathrm{O}_{3}, 3 \times 2 \mathrm{~min}$; tap-water, $10 \mathrm{~min}$; distilled water, $5 \mathrm{~min}$; $95 \%$ ethanol, $2 \times 5 \mathrm{~min}$; absolute ethanol, $2 \times 5 \mathrm{~min}$; toluene, $2 \times 5 \mathrm{~min}$; mounting in Harleco's synthetic resin. An unhydrolysed control smear was included in each staining procedure. All slides received the same treatment. Smears from ejaculated spermatozoa from different rabbits were stained back to back in the same bath. When a rabbit was slaughtered, all slides from that animal followed, back to back, the same procedure.

\section{Smears for UV absorption measurements}

Smears were prepared in duplicate on quartz slides, fixed above $40 \%$ formaldehyde at room temperature for $15 \mathrm{~min}$, dehydrated in absolute ethanol and mounted in glycerol using quartz cover-glasses.

\section{Light absorption determinations}

All the DNA measurements, both at $560 \mathrm{~m} \mu$ and at $260 \mathrm{~m} \mu$, were performed on twenty individual spermatozoa in the fully automatic 'Universalmikrospektrophotometer UMSP I Zeiss' which scans the entire nucleus and integrates the optical densities from subsequent scannings (Caspersson, Carlson \& Svensson, 1954). By multiplying the integrated optical density by the integration coefficient, the total amount of DNA/spermatozoon, expressed in arbitrary units, can be obtained. For determinations in the uv-range, duplicate measurements were also made at $315 \mathrm{~m} \mu$ and the integrated optical density at $315 \mathrm{~m} \mu$ subtracted from the value at $260 \mathrm{~m} \mu$ in order to eliminate unspecific light losses.

\section{RESULTS}

Variation in the content of Feulgen-DNA and $U V-D \mathcal{N} A$ of ejaculated spermatozoa within and between rabbits

In normal rabbit semen, although routine semen examinations suggested that spermatogenesis occurred normally, the Feulgen-DNA content of spermatozoa contained in the first ejaculate was very variable: overall $X$ from fifteen ejaculates was $4 \cdot 26 \pm 1 \cdot 07 ; C=0 \cdot 25$. It is interesting, too, that the highest coefficients of variation ( $C=0 \cdot 10$ or higher) were found in ejaculates with mean Feulgen-DNA values below $4 \cdot 00$, suggesting that these ejaculates contained a 
mixture of cells with normal Feulgen-DNA values and of cells with a decreased amount of Feulgen-DNA.

Variability was also observed between different ejaculates of the same rabbit. The mean Feulgen-DNA for thirty-three ejaculates collected from the fifteen rabbits was $4.40 \pm 0.91, C=0.21$; again there was a negative correlation between the Feulgen-DNA and the coefficient of variation in these ejaculates. The mean Feulgen-DNA values for the first, second and third ejaculates were $4.20,4.56$ and 4.47 , respectively; thus the Feulgen-DNA contents were not related to the order in which the ejaculates were collected.

From two rabbits (Nos. 1 and 2) seven ejaculates were collected after the hot water application to the testes, and the spermatozoa Feulgen-stained. Although the heat treatment caused severe testicular degeneration (pycnotic spermatozoa, deformed sperm heads, decreased motility and concentration; even complete aspermia in rabbit No. 1) the mean Feulgen-DNA $(\bar{X}=5 \cdot 12)$ was not statistically different from the mean value obtained in the same two rabbits before treatment $(\bar{X}=5 \cdot 12)$.

In contrast to the Feulgen-DNA values, those relating to the UV-DNA content of ejaculated spermatozoa were very similar for different animals: $X=5 \cdot 18$ $\pm 0.08 ; C=0.015$. The same applied to values for different ejaculates of the same rabbits, $\bar{X}$ being $5 \cdot 21 \pm 0 \cdot 11 ; C=0 \cdot 02$.

Comparative study of the Feulgen-DNA and $U V-D \mathcal{N A}$ content of spermatozoa recovered from different parts of the male reproductive tract

The results of the experiments relating to the DNA content of spermatozoa recovered from different parts of the male reproductive tract are summarized in Table 1.

In untreated animals the high standard deviation $(\bar{X}=4.06 \pm 1.06)$ and coefficient of variation $(C=0.26)$ after Feulgen staining suggest the existence of a marked variability in Feulgen stainability (rabbits Nos. 3, 6 and 10). A gradual decrease in the Feulgen-DNA content is shown by spermatozoa of these rabbits as they traverse from the caput $(\bar{X}=4.95)$ to the cauda $(\bar{X}=4.50)$ and to the ampulla $(\bar{X}=2 \cdot 98)$; ejaculated spermatozoa $(\bar{X}=4 \cdot 11)$ occupy an intermediate position between those from the epididymis and ampulla. The least significant difference (LSD) (Tukey test; Snedecor, 1962) being 1.50, the Feulgen-DNA content in the ampulla is significantly lower than either in the caput or in the cauda epididymidis $(P<0.05)$. Between caput and cauda the difference is not significant. The lower content of Feulgen-DNA in ampullary spermatozoa suggests that an ageing effect occurs in spermatozoa in vivo.

Concerning spermatozoa obtained from rabbits with induced testicular damage, the spermatozoa recovered from different parts of the male tract gave, after treatment, a mean Feulgen-DNA value $(\bar{X}=4.30 \pm 1.51 ; C=0.35)$ which was not significantly different from the mean value before treatment. Again, however, the ageing effect along the male ducts was obvious: the mean Feulgen-DNA for the caput epididymidis was 5.01 , for the cauda 4.73 and for the ampulla 3.57; ejaculates showed an intermediate position, namely, 4.00. The LSD being 0.72 , the spermatozoa from ejaculates and ampulla can be regarded as having a significantly lower Feulgen-DNA value than those from 
TABLE 1

MEAN CONTENTS OF FEULGEN-DNA AND UV-DNA $(\bar{X})$ AND STANDARD DEVIATION (st.d.) IN SPERMATOZOA RECOVERED FROM DIFFERENT PARTS OF THE RABBIT REPRODUCTIVE TRACT

\begin{tabular}{|c|c|c|c|c|c|}
\hline \multirow{2}{*}{$\begin{array}{l}\text { Rabbit } \\
\text { No. }\end{array}$} & \multirow{2}{*}{$\begin{array}{c}\text { Origin of } \\
\text { spermatozoa }\end{array}$} & \multicolumn{2}{|c|}{ Feulgen-DNA } & \multicolumn{2}{|c|}{$U V-D \mathcal{N} A$} \\
\hline & & $\bar{X}$ & st.d. & $\bar{X}$ & st.d. \\
\hline 3 & $\begin{array}{l}\text { Ejaculate } \\
\text { Caput epid. } \\
\text { Cauda epid. } \\
\text { Ampulla }\end{array}$ & $\begin{array}{l}4 \cdot 23 \\
4 \cdot 73 \\
4 \cdot 85 \\
2 \cdot 86\end{array}$ & $\begin{array}{l}0 \cdot 16 \\
0 \cdot 20 \\
0 \cdot 85 \\
1 \cdot 12\end{array}$ & & \\
\hline 6 & $\begin{array}{l}\text { Ejaculate } \\
\text { Caput epid. } \\
\text { Cauda epid. } \\
\text { Ampulla }\end{array}$ & $\begin{array}{l}2 \cdot 92 \\
3 \cdot 81 \\
3 \cdot 56 \\
3 \cdot 07\end{array}$ & $\begin{array}{l}0 \cdot 30 \\
0 \cdot 74 \\
0 \cdot 36 \\
0 \cdot 45\end{array}$ & $\begin{array}{l}5 \cdot 20 \\
5 \cdot 16 \\
5 \cdot 25 \\
5 \cdot 12\end{array}$ & $\begin{array}{l}0 \cdot 19 \\
0 \cdot 34 \\
0 \cdot 23 \\
0 \cdot 26\end{array}$ \\
\hline 10 & $\begin{array}{l}\text { Ejaculate } \\
\text { Caput epid. } \\
\text { Cauda epid. } \\
\text { Ampulla }\end{array}$ & $\begin{array}{l}4 \cdot 27 \\
6 \cdot 31 \\
5 \cdot 09 \\
3 \cdot 02\end{array}$ & $\begin{array}{l}0 \cdot 19 \\
0 \cdot 40 \\
0 \cdot 55 \\
1 \cdot 41\end{array}$ & $\begin{array}{l}5 \cdot 38 \\
5 \cdot 27 \\
5 \cdot 16 \\
5 \cdot 17\end{array}$ & $\begin{array}{l}0 \cdot 27 \\
0 \cdot 28 \\
0 \cdot 27 \\
0 \cdot 28\end{array}$ \\
\hline 4 & $\begin{array}{l}\text { Ejaculate } \\
\text { Caput epid. } \\
\text { Cauda epid. } \\
\text { Ampulla }\end{array}$ & $\begin{array}{l}2 \cdot 25 \\
2 \cdot 71 \\
2 \cdot 10 \\
1 \cdot 72\end{array}$ & $\begin{array}{l}0.40 \\
1.26 \\
0.68 \\
0.66\end{array}$ & & \\
\hline 5 & $\begin{array}{l}\text { Ejaculate } \\
\text { Caput epid. } \\
\text { Cauda epid. } \\
\text { Ampulla }\end{array}$ & $\begin{array}{l}3 \cdot 31 \\
4.79 \\
1 \cdot 60 \\
0 \cdot 67\end{array}$ & $\begin{array}{l}0 \cdot 33 \\
1.40 \\
0 \cdot 52 \\
0 \cdot 32\end{array}$ & & \\
\hline 7 & $\begin{array}{l}\text { Ejaculate } \\
\text { Caput epid. } \\
\text { Cauda epid. } \\
\text { Ampulla }\end{array}$ & $\begin{array}{l}4 \cdot 55 \\
5 \cdot 31 \\
4.98 \\
3.58\end{array}$ & $\begin{array}{l}0 \cdot 30 \\
0 \cdot 24 \\
0 \cdot 34 \\
0 \cdot 74\end{array}$ & $\begin{array}{l}5 \cdot 12 \\
5 \cdot 07 \\
5 \cdot 11 \\
4 \cdot 97\end{array}$ & $\begin{array}{l}0.51 \\
0.20 \\
0.24 \\
0.24\end{array}$ \\
\hline 8 & $\begin{array}{l}\text { Ejaculate } \\
\text { Caput epid. } \\
\text { Cauda epid. } \\
\text { Ampulla }\end{array}$ & $\begin{array}{l}2 \cdot 70 \\
5 \cdot 28 \\
5 \cdot 09 \\
4 \cdot 06\end{array}$ & $\begin{array}{l}0 \cdot 38 \\
0 \cdot 39 \\
0 \cdot 37 \\
0 \cdot 37\end{array}$ & $\begin{array}{l}5 \cdot 28 \\
5 \cdot 21 \\
5 \cdot 17 \\
5 \cdot 25\end{array}$ & $\begin{array}{l}0.27 \\
0.22 \\
0.21 \\
0.30\end{array}$ \\
\hline 9 & $\begin{array}{l}\text { Ejaculate } \\
\text { Caput epid. } \\
\text { Cauda epid. } \\
\text { Ampulla }\end{array}$ & $\begin{array}{l}4 \cdot 60 \\
5 \cdot 11 \\
4 \cdot 72 \\
4 \cdot 91\end{array}$ & $\begin{array}{l}0.22 \\
0 \cdot 41 \\
0 \cdot 27 \\
0 \cdot 40\end{array}$ & $\begin{array}{l}5 \cdot 32 \\
5 \cdot 28 \\
5 \cdot 18 \\
5 \cdot 21\end{array}$ & $\begin{array}{l}0.26 \\
0.27 \\
0.22 \\
0.35\end{array}$ \\
\hline 11 & $\begin{array}{l}\text { Ejaculate } \\
\text { Caput epid. } \\
\text { Cauda epid. } \\
\text { Ampulla }\end{array}$ & $\begin{array}{l}4 \cdot 44 \\
5 \cdot 58 \\
6 \cdot 22 \\
4 \cdot 19\end{array}$ & $\begin{array}{l}0.74 \\
0 \cdot 74 \\
0.28 \\
0.75\end{array}$ & $\begin{array}{l}5 \cdot 20 \\
5 \cdot 12 \\
5 \cdot 10 \\
5 \cdot 09\end{array}$ & $\begin{array}{l}0.26 \\
0.32 \\
0.36 \\
0 \cdot 16\end{array}$ \\
\hline 12 & $\begin{array}{l}\text { Ejaculate } \\
\text { Caput epid. } \\
\text { Cauda epid. } \\
\text { Ampulla }\end{array}$ & $\begin{array}{l}5 \cdot 23 \\
\\
6 \cdot 59 \\
4 \cdot 88\end{array}$ & $\begin{array}{l}0 \cdot 19 \\
0 \cdot 36 \\
0 \cdot 15\end{array}$ & $\begin{array}{l}5 \cdot 10 \\
5 \cdot 13 \\
5 \cdot 13 \\
5 \cdot 22\end{array}$ & $\begin{array}{l}0.20 \\
0 \cdot 15 \\
0.32 \\
0.32\end{array}$ \\
\hline 13 & $\begin{array}{l}\text { Ejaculate } \\
\text { Caput epid. } \\
\text { Cauda epid. } \\
\text { Ampulla }\end{array}$ & $\begin{array}{l}5 \cdot 08 \\
6 \cdot 29 \\
6 \cdot 55 \\
4 \cdot 52\end{array}$ & $\begin{array}{l}0.20 \\
0 \cdot 32 \\
0 \cdot 42 \\
0 \cdot 39\end{array}$ & $\begin{array}{l}5 \cdot 12 \\
5 \cdot 20 \\
5 \cdot 12 \\
5 \cdot 07\end{array}$ & $\begin{array}{l}0.20 \\
0.32 \\
0.25 \\
0.26\end{array}$ \\
\hline
\end{tabular}


the caput or the cauda; on the other hand, the difference between caput and cauda is not significant $(P<0 \cdot 05)$.

The UV-DNA values in spermatozoa which had been recovered from different sites of the efferent ducts before treatment were much more constant $(\bar{X}=5 \cdot 19$ $\pm 0.058 ; C=0.01)$ than the Feulgen-DNA values $(\bar{X}=4.06 \pm 1.06 ; C=0.26)$; no correlation with the site of collection can be seen in the UV-DNA values.

The UV-DNA contents of spermatozoa obtained from different parts of the tract after treatment show a very small standard deviation $(X=5 \cdot 15 \pm 0.076)$ and coefficient of variation $(C=0 \cdot 015)$, typical for a homogeneous cell population. Furthermore, no significant differences were observed to exist between the rabbits, between the sites of collection or between treated and untreated animals.

\section{Influence of an experimental vasoligation}

In order to test the hypothesis that the decrease of Feulgen-DNA is brought about by an ageing process in vivo, a ligature was placed on the right vas deferens in two rabbits caudally from the cauda epididymidis, while the left vas deferens was left intact. Table 2 lists the results obtained when the animals

TABLE 2

INFLUENCE OF A LIGATURE PLACED ON THE RIGHT VAS DEFERENS ON THE DNA CONTENT OF SPERMATOZOA IN THE CAPUT EPIDIDYMIDIS, CAUDA EPIDIDYMIDIS (PROXIMAL AND DISTANT PORTION) AND AMPULLA

\begin{tabular}{|c|c|c|c|c|}
\hline & \multicolumn{2}{|c|}{$\begin{array}{c}\text { Rabbit No. } 14 \\
(15 \text { days })\end{array}$} & \multicolumn{2}{|c|}{$\begin{array}{l}\text { Rabbit No. } 15 \\
\quad(30 \text { days })\end{array}$} \\
\hline & Left side & Right side & Left side & Right side \\
\hline $\begin{array}{l}\text { UV-DNA } \\
\text { Caput epid. } \\
\text { Cauda prox. } \\
\text { Cauda dist. } \\
\text { Ampulla }\end{array}$ & $\begin{array}{l}5 \cdot 92 \\
5 \cdot 96 \\
5 \cdot 91 \\
5 \cdot 86\end{array}$ & $\begin{array}{l}5 \cdot 93 \\
5 \cdot 89 \\
5 \cdot 80\end{array}$ & $\begin{array}{l}5 \cdot 79 \\
5 \cdot 95 \\
5 \cdot 96 \\
5 \cdot 57\end{array}$ & $\begin{array}{l}6 \cdot 33 \\
5 \cdot 81 \\
5 \cdot 59\end{array}$ \\
\hline $\begin{array}{l}\text { Feulgen-DNA } \\
\text { Caput epid. } \\
\text { Cauda prox. } \\
\text { Cauda dist. } \\
\text { Ampulla }\end{array}$ & $\begin{array}{l}7 \cdot 47 \\
7 \cdot 15 \\
7 \cdot 57 \\
6 \cdot 18\end{array}$ & $\begin{array}{l}7.84 \\
6 \cdot 84 \\
6 \cdot 87\end{array}$ & $\begin{array}{l}7 \cdot 31 \\
7 \cdot 07 \\
6 \cdot 93 \\
4 \cdot 24\end{array}$ & $\begin{array}{l}7 \cdot 02 \\
6 \cdot 92 \\
5.55\end{array}$ \\
\hline
\end{tabular}

were slaughtered after 15 days (No. 14) and 30 days (No. 15). In spermatozoa obtained from the ampulla on the non-ligated side a decreased Feulgen-DNA value was observed, thus confirming the previous experiments. Vasoligation, and consequently an enforced arrest of spermatozoa in the epididymis, resulted in a significantly lowered Feulgen-DNA content in the cauda; this was more pronounced after 30 days ligation than after 15 days. However, even after the 30 days ligation period, the Feulgen-DNA values in the cauda epididymidis were still higher than in the intact ampulla. The UV-DNA contents, on the other hand, were not significantly influenced by the ligation. 
Length of the acid hydrolysis period in relation to Feulgen-stainability of ejaculated spermatozoa

Although the above described experiments showed clearly that a marked decrease in Feulgen-DNA occurs as spermatozoa traverse along the male tract, the mechanism underlying the phenomenon of decreased response to the Feulgen stain remained unexplained. One plausible explanation might be that during storage in the male reproductive tract the purine-sugar linkages become more fragile and sensitive to hydrolysis in $\mathrm{N}-\mathrm{HCl}$ at $60^{\circ} \mathrm{C}$. To test this hypothesis, acid-hydrolysis curves were determined for ejaculates with normal and with low Feulgen-DNA in spermatozoa (Table 3). However, for both types

TABLE 3

INFLUENCE OF THE ACID-HYDROLYSIS PERIOD ON THE FEULGEN-STAINABILITY OF SPERMATOZOA IN TWO EJAGULATES, ONE WITH LOW DNA-VALUE (EJAGulate No. 1) AND THE OTHER WITH high DNA-VAlue (EJAGulate No. 2)

\begin{tabular}{|c|c|c|c|c|c|}
\hline \multirow{2}{*}{ Ejaculate } & & \multicolumn{4}{|c|}{ Hydrolysis time } \\
\hline & & $8 \min$ & $10 \min$ & $12 \min$ & $16 \min$ \\
\hline No. 1 & $\begin{array}{l}\text { Replicate } 1 \\
\text { Replicate } 2\end{array}$ & $\begin{array}{l}4.00 \pm 0.24 \\
3 \cdot 81 \pm 0.22\end{array}$ & $\begin{array}{l}4.00 \pm 0.24 \\
4.04 \pm 0.20\end{array}$ & $\begin{array}{l}3 \cdot 93 \pm 0 \cdot 21 \\
4 \cdot 10 \pm 0.20\end{array}$ & $\begin{array}{l}3.29 \pm 0.32 \\
3.70 \pm 0.36\end{array}$ \\
\hline No. 2 & $\begin{array}{l}\text { Replicate } 1 \\
\text { Replicate } 2\end{array}$ & $\begin{array}{l}5 \cdot 02 \pm 0.24 \\
4 \cdot 96 \pm 0.26\end{array}$ & $\begin{array}{l}5 \cdot 15 \pm 0 \cdot 22 \\
5 \cdot 18 \pm 0 \cdot 24\end{array}$ & $\begin{array}{l}5 \cdot 18 \pm 0.22 \\
5 \cdot 16 \pm 0 \cdot 20\end{array}$ & $\begin{array}{l}4 \cdot 43 \pm 0.36 \\
4 \cdot 20 \pm 0.38\end{array}$ \\
\hline
\end{tabular}

of ejaculates the curves were similar, showing a flat top between 10 and $12 \mathrm{~min}$ of hydrolysis. This finding conforms with a previous statement (Bouters, Baker \& Salisbury, 1965) that rabbit spermatozoa need a longer hydrolysis time than do bovine spermatozoa, but that the shape of the curves for both types of ejaculates is the same.

\section{DISCUSSION}

All of the rabbits selected for our study exhibited good quality of ejaculated semen (as assessed by volume, sperm concentration, vital staining and morphology), which suggests that their spermatogenesis was normal. Nevertheless, both ejaculated spermatozoa, as well as those recovered from different parts of the male tract, showed high variability in respect of Feulgen stainability. The spermatozoa recovered from the ampulla showed always significantly lower Feulgen-DNA values than those from the epididymis. In the epididymis itself there was a decrease from the caput to the cauda but that difference was not statistically significant. These observations strongly suggest that an ageing effect occurring in vivo is responsible for decreased Feulgen-stainability, and that this effect is localized mainly in the ampulla. Ligation of the vas deferens also affected the Feulgen-DNA in the ligated epididymis but never to the same extent as in the ampulla. Ampullary secretion may play perhaps some role in the process. A similar phenomenon of a decrease in spermatozoal Feulgen-DNA has been noticed by Salisbury, Birge, de la Torre \& Lodge (1961) and by 
Hanada, Hiroe \& Tomizuka (1965) during storage of diluted spermatozoa in vitro. However, if the decrease in Feulgen-stainability is due to an ageing process, one would expect to find the oldest sperm cells, and thus the lowest Feulgen-DNA values, in the first ejaculate. This is not so: no significant difference in FeulgenDNA was found between three consecutive ejaculates of the fifteen experimental rabbits. However, recently it has been demonstrated (Orgebin-Crist, 1965) that during epididymal passage, younger and older sperm cell populations are mixed. In contrast to the results obtained by the Feulgen-DNA determinations, very constant results were obtained by uv microspectrophotometry; ageing had no influence upon UV-DNA of spermatozoa. The reason for the decreasing Feulgen-stainability cannot be partial depurinization. The hypothesis that during storage the purine-sugar linkage could become more sensitive to hydrolysis is also invalidated by the observation that the hydrolysis curves for spermatozoa with a low and a high mean Feulgen-DNA had the same shape. The most plausible explanation for the decrease in Feulgen-positive material which occurs in spermatozoa during their passage along the male tract is that this results from structural changes in DNA, since it is known that maturation of spermatozoa is accompanied by a process of a more tight 'packing' of the chromatin and by changes in the nuclear protein from histone to a more basic arginine-rich protein (Monesi, 1965). Gledhill (1966) and Gledhill, Gledhill, Rigler \& Ringertz (1966) found a similar decrease of Feulgen-DNA in elongated spermatids in bulls during their transformation to spermatozoa and subsequent epididymal passage. They also attribute this decrease in Feulgen stainability to changes in the spermatozoal nucleoprotein. Moreover, it is known that the nature of protein may affect the stoichiometry of the Feulgen reaction (Walker \& Richards, 1959). In view of the fact that the results of DNA determinations in rabbit spermatozoa are completely different according to the choice of the microspectrophotometric method, it is not surprising that different authors, using different quantitative methods for DNA determinations, should have reached contradictory conclusions as regards the correlation between the DNA-content of spermatozoa and their fertilizing capacity.

\section{ACKNOWLEDGMENTS}

This research was supported in part by an award from the Lalor Foundation, Wilmington, Delaware, U.S.A., to the senior author.

The authors wish to thank Dr P. Lampo for the help in statistical analysis of the material and J. C. Nicolle, F. N. Baker and D. Vereecke for technical assistance.

\section{REFERENCES}

Baker, F. N. \& Salisbury, G. W. (1963) Nuclear size of live and dead bovine spermatozoa. Nature, Lond. 197, 820.

Bouters, R., Baker, F. N. \& Salisbury, G. W. (1965) Feulgen staining of rabbit spermatozoa: hydrolysis time and homogenicity of distribution of chromatin. Stain Technol. 40, 193.

BOUTERS, R. \& VANDEPLASSCHE, M. (1964) Veränderungen im Bullen-samen nach experimenteller Infektion mit einem Enterovirus. Berl. Münch. tierärztl. Wschr. 77, 87.

Caspersson, T., Carlson, L. \& Svensson, G. (1954) A scanning interference microscope arrangement. Expl Cell Res. 7, 601. 
Di Stefano, H. (1948) A cytochemical study of the Feulgen nucleal reaction. Chromosoma, 3, 282.

Feulgen, R. \& Rossenbeck, H. (1924) Microskopisch-chemischer Nachweis einer Nukleinsaure vom Typus der Thymonukleinsaure und die darauf beruhende elektive Farbung von Zellkernen in Mikroskopischen Präparaten. Hoppe-Seyler's Z. physiol. Chem. 135, 203.

GLEDHILl, L. (1966) Studies on the DNA content, dry mass and optical area of bull spermatozoal heads during epididymal maturation. Acta vet. scand. 7, 1.

Gledhill, L., Gledhill, M. P., Rigler, R. \& Ringertz, N. R. (1966) Changes in deoxyribonucleoprotein during spermiogenesis in the bull. Expl Cell Res. 41, 652.

Hanada, A., Hiroe, K. \& Tomizuka, T. (1965) DNA content in bull spermatozoa during storage in yolk citrate diluent at $4^{\circ}$ C. Jap. F. Anim. Reprod. 10, 103.

LeUChtENBERger, C. (1960) The relation of the deoxyribosenucleic acid (DNA) of sperm cells to fertility. 4th bien. Symp. Anim. Reprod., Illinois, Suppl. 7. Dairy Sci. 43, 31.

MonesI, V. (1965) Synthetic activities during spermatogenesis in the mouse. RNA and protein. Expl Cell Res, 39, 197.

Orgebin-CRIst, M. C. (1965) Passage of spermatozoa labelled with Thymidine- ${ }^{3} \mathrm{H}$ through the ductus epididymis of the rabbit. F. Reprod. Fert. 10, 241.

Parez, M., Petel, J. P. \& Vendrely, C. (1960) Sur la teneur en acide déoxyribonucléique des spermatozoides de taureaux présentants différents dégrés de fécondité. C. r. hebd. Séanc. Acad. Sci., Paris, 251, 2581.

Salisbury, G. W., Birge, W. J., de LA Torre, L. \& Lodge, J. R. (1961) Decrease in nuclear Feulgenpositive material (DNA) upon aging in in vitro storage of bovine spermatozoa. 7. biophys. biochem. Cytol. $10,353$.

SNedecor, G. W. (1962) Statistical methods, 5th edn, p. 534. Iowa State College Press.

Summerhill, W. R, \& Ords, D. (1961) Levels of deoxyribonucleic acid in bovine spermatozoa and their relationship to fertility. F. Dairy Sci. 44, 548.

WALKeR, P. M. B. \& Richards, B. M. (1959) Quantitative microscopical techniques for single cells. In: The Cell : Biochemistry, Physiology, Morphology. Vol. I, p. 816. Eds. Brachet and Mirsky. Academic Press, New York.

Weir, D. R. \& Leuchtenberger, C. (1957) Low sperm deoxyribose nucleic acid as possible cause for otherwise unexplained human infertility. Fert. Steril. 8, 373.

Welch, R. M., Hanly, E. W. \& Guest, W. (1961) The deoxyribonucleic acid (DNA) deviation in the semen spermatozoa of bulls of unknown fertility under two years of age and its relationship to motility, count and morphology. F. Morph. 108, 145. 